\title{
O ESTÍMULO NA PARTICIPAÇÃO DO ALUNO DE EAD ATRAVÉS DA ARTE DO FEEDBACK
}

Rosimeire Aparecida de Sousa, Maria Eliza Nigro Jorge

Universidade do Oeste Paulista - UNOESTE. Aperfeiçoamento Tutoria em EAD, Presidente Prudente - SP. E-mail: rosimeiresousa@gmail.com

\section{RESUMO}

O aluno necessita em seu aprendizado de um trabalho efetivo do professor/tutor para que possa não se sentir sozinho diante do curso de EAD. Neste momento surge o feedback, ao mesmo tempo que este é a forma avaliativa da aprendizagem. O feedback origina não somente como forma de resposta ao aluno, mas também como forma de conhecimento por parte do professor quanto à sua metodologia de ensino e se está coerente com os objetivos do curso, para que possa fazer as devidas correções dentro do tempo, espaço e cultura. O feedback é uma ponte e arte na motivação e estímulo para que o aluno continue seus estudos e colabore com seu próprio processo de conhecimento.

Palavras-chave: EAD1; feedback2; motivação3; aprendizagem4.

\section{THE STIMULUS ON THE STUDENT'S PARTICIPATION OF EAD THROUGH THE ART OF FEEDBACK}

\begin{abstract}
The student needs in their learning of an effective work of the teacher / tutor to help you not feel alone before the ODL course. At this time feedback arises, while this is evaluative form of learning. The feedback originates not only as a response to the student, but also as a form of knowledge from the teacher about their teaching methodology and is consistent with the objectives of the course, so you can make corrections in time, space and culture. Feedback is a bridge and art in motivation and encouragement for students to continue their studies and work with their own process knowledge.
\end{abstract}

Keywords: ODL1; feedback2; motivation3; learning4. 


\section{INTRODUÇÃO}

O aluno de EAD necessita de uma identificação a mais junto ao seu curso, demais colegas e equipe colaborativa, dentre estes os professores e tutores. A evasão é fator que o absorve e que se interpõe diante das necessidades que o influenciaram a buscar este recurso de ensino. Neste contexto e partindo da atualização de conhecimento buscamos neste trabalho efetuar um estudo sobre o estímulo e a arte que se faz presente através do feedback para que o aluno não desista e participe ativamente do curso, sendo o maior beneficiado, como também um influenciador enquanto representante da instituição.

\section{METODOLOGIA}

O presente trabalho foi realizado através de pesquisas bibliográficas e conclusões pessoais junto aos desenvolvidos no curso de Aperfeiçoamento de Tutoria em EAD, uma revisão contextualizada e baseada na captação e compreensão do conhecimento.

\section{RESULTADOS}

Os resultados obtidos foram positivos, pois além de captarem opostos dentro da formação também diagnosticaram pontos onde podem ser mais bem trabalhados, possibilitando com que haja uma difusão deste conhecimento, um estímulo com arte e um feedback integral por seus professores e tutores. Estes pontos também servem para futuros estudos e novas discussões que podem se originar após este trabalho.

\section{DISCUSSÃO}

O desenvolvimento do trabalho se deu inteiramente através de uma ideia, de contextualização e compreensão, partindo-se de alguns pressupostos que estão enumerados a seguir, buscamos efetuar uma visualização e colaborativa para futuras discussões. Esperamos que este trabalho não se feche em si, mas sim que seja cíclico e possa dar origem a novos trabalhos.

\section{O QUE É FEEDBACK?}

A palavra feedback vem do inglês e possui nos seus significados: feed - alimento, nutrir, inspirar e back: auxiliar, devolver, repor. Em tradução livre poderíamos compô-la como devolução de alimento, ou retroalimentação. É a resposta, integração entre partes envolvidas de um mesmo processo, por muitos considerado novo, porém antigo e muito utilizado em seus princípios e métodos, a nomenclatura é bem difundida na área da Administração, e tem-se tornado comum 
nas áreas, inclusive na educação. Trabalha o retorno permanente para que perguntas sejam respondidas, ou fornecidas àquelas iminentes possibilitando o aprendizado, fechando ciclos, novos debates e interações.

\section{A FIGURA DO FEEDBACK NA EDUCAÇÃO}

Quando falamos em feedback na educação é interessante mencionarmos que respostas fazem-se necessárias em todas as formas de aprendizado, sejam no presencial (síncrono) ou à distância (assíncrono), onde o professor fica como central e interacional com a equipe formativa e os discentes que esperam para dialogarem e terem seus pensamentos agregados e completados para um crescimento coeso e conjunto associado. O professor passa a ter domínio e responsabilidade de indicar, relacionar, apoiar e praticar a interação de forma que os alunos se sintam livres para participar. As responsabilidades e o trabalho são maiores no início, até que consiga a fluência de todos, não se tornando fácil, mas diferente, do acolhedor, passa a ser guia nas atividades, participação, trabalhos, leituras, indicador e receptor de novas ideias agora fornecidas pelos alunos que contribuem e elaboram novos métodos de ensino e feedback.

\section{MISSÃO DA EAD: ENSINAR MESMO EM PROCESSO ASSÍNCRONO}

A missão da EAD é levar o conhecimento, independente da distância e localidade, possibilitando sua disseminação. O aluno muitas vezes acredita que a EAD é fácil e não séria, que terá aprovação somente por estar matriculado. Que a EAD tem sua validade questionável, o que pode estar longe da realidade, pois depende de efetiva participação. Sua formação é autônoma, o curso terá atividades como os presenciais e obrigações enquanto aluno, devendo corresponder às expectativas e alçar metas propostas para sua aprovação. O aluno vê a distância como barreira entre ele e o professor, esquecendo-se que esta distância não deve ser vista assim e sim como ponte a facilitar o ensino, abertura para variar a socialização, alavancar e ultrapassar limites. Outro ponto a ser destacado neste tipo de ensino junto sua visualização no mercado é quanto ao ainda forte questionamento da qualidade de formação de seus egressos. Na matéria de Martins e Moço (2009) há menção do crescimento do ensino a distância e o medo dos concluintes no mercado devido à desconfiança dos empregadores perante o ensino. Por serem de forma assíncrona os temores estão arraigados na cultura de nossa sociedade, uma sociedade acostumada com o ensino tradicional onde o aluno necessita estar presente na sala de aula. A melhoria na qualidade do ensino em EAD assim como de seus formandos vai destes ao buscar instituições comprometidas não somente com boa formação como com bons resultados na mão-de-obra o 
que poderá indicá-la junto à sociedade. O ensino é somente um, porém com métodos diferenciados que podem não condizer com a compreensão, trabalho, visualização de toda a equipe envolvida, o aluno deve entender que mesmo não sendo com atividades trabalhadas no dia-a-dia, estas também possuem datas, prazos, sem direito a postergações, o que influencia em suas notas, conceitos e nele como aluno. Antigamente acreditava-se que apenas uma formação seria suficiente, uma carreira a seguir; hoje o mundo está em constante evolução e não adianta apenas um estudo, um curso, ou um diploma para estar e considerar-se apto, o mundo gira e rápido, os alunos não podem permanecer no marasmo e muitos já observaram este fator, mesmo participando de cursos presenciais fazem cursos a distância. Ou mesmo diante das dificuldades enfrentadas pelo dia-a-dia, até mesmo em sua primeira formação e da necessidade partem para estudos assíncronos, gerando um grande alvo para as mais variadas instituições. Algumas sérias outras nem tanto, mas todas buscando integrar o aluno a seus conteúdos, depende muito da capacidade do aluno em garimpar a melhor e que se adeque aos seus meios, necessidades, condições e que estejam credenciadas junto aos órgãos reguladores e educacionais. A lentidão é outro fator que gera a busca por instituições à distância, a necessidade de capacitação, de preparação de qualidade e de agilidade para cumprir metas. Parte do aluno a adaptação, também o seu interesse e o que buscará na instituição: como influências, motivação, a arte do feedback, corpo institucional, equipe qualificada, quadro docente interessado e capaz de criar laços afetivos, sociais, culturais e de conseguirem que estes alunos interajam com os demais de forma que todos possam ter avanço semelhante, igualitário e total aprendizado.

\section{MOTIVAÇÃO, INFLUÊNCIA E/OU DESGASTE NO PROCESSO DA EDUCAÇÃO}

A motivação deve ser constante, o aluno não pode ficar inerte e nem submisso a uma má qualificação. A instituição deve ser íntegra e primar pela valorizarização do capital humano, seja no corpo docente ou em seus alunos que serão propagadores de sua filosofia, respeitabilidade, qualidade, junto ao meio acadêmico, produtor e difusor de ideias, conceitos e filosofias. 0 desgaste se inicia quando o aluno não consegue ter boas influências através de uma instituição preocupada com o seu aprendizado, ela deve estar comprometida, e o aluno deve entender a necessidade de seu próprio estímulo como constante e flexível. A EAD origina um fluxo no processo. O passo inicial é de interesse do aluno que participa deste processo. Por se tratar de metodologia de ensino atualmente no ciberespaço, o aluno deve possuir referências, pessoas que o auxiliem em um primeiro momento ou que o socializem nas novas tecnologias utilizadas. Motivando, incentivando para que possa entrar no AVA e ter seus primeiros contatos com a turma 
e seus professores/tutores. Pessoas que já tenham realizado cursos semelhantes é interligação entre instituições e alunos, propagadoras e egressos bem sucedidos podem partilhar suas experiências como estímulo para iniciantes, para que entendam a importância, interesse e participação neste trabalho e estudo. Quando falamos do desgaste no processo educacional nos referimos à falta de motivação, capacitação dos professores para atuarem de modo a obter melhores resultados. $O$ desgaste também pode vir da repetição, falta e desinteresse de novidades, não movimentação da instituição para que tanto seu corpo docente como também seus alunos evoluam. A instituição deve valorizar seu corpo docente para que criem novos métodos, aprimorem-se, colaborem com a qualificação de seus cursos, agregando e enriquecendo, assim contribuindo positivamente em sua própria formalização. Nestes dois pontos opostos estão à influência positiva ou negativa que trata do desgaste, estes pontos interferem no processo diário e evolutivo do feedback realizado e aproveitado por parte do aluno e da equipe envolvida. 0 desgaste gera péssima imagem, decadência, desânimo por parte de todos, evasão, não participação, falta de integração, desmotivação e ausência do aluno, como também do professor em âmbito educacional e social na comunidade acadêmica ou regional. Para contrabalancear os positivos e negativos temos duas vertentes, a afetividade considerada vital e de grande importância no positivo e a evasão que é o extremo no negativo. São teses divergentes, mas se complementam ao estudarmos o desgaste e a motivação, que acarreta um e outro ao mesmo tempo que origina e decepciona o aluno do ensino em EAD.

\section{FEEDBACK E AFETIVIDADE: ARTE, MOTIVAÇÃO, ESTíMULO NA EDUCAÇÃo ATRAVÉS DA EAD}

O aluno no processo educacional cria com seus professores/tutores, vínculos: afetivos, interacionais, sociais. Nosso foco é o feedback e a afetividade dentro do processo educacional à distância. O aluno acostumado com o método tradicional de ensino inicialmente se sente deslocado e incerto, pois não encontra uma sala de aula como até então teve. Nesta necessidade de encontrar-se e sem conhecer detalhes dos colegas virtuais, tem maior interação com seu tutor que é aquele que em um primeiro momento e instância o responde, mostrando o ensino, como usufruir da EAD. Com este trabalho cria-se um laço afetivo a ser muito bem trabalhado por ambas as partes, pois o laço sincero possibilita liberdade para que se exponham, questionem mais, sem medos ou temores. Por parte do professor esta também se torna benéfica ao passo que se sente mais talhado para descrever o processo evolutivo, retornar as perguntas, questionar respostas mais diretas, incisivas ou mesmo contrariando a resposta dada, orientar o que foi dito, efetuar devoluções práticas por parte dos seus alunos quando não se conseguiu até então obtê-las. 0 
aluno não se sente subjugado e sim capacitado, não se sente condenado e sim compreende a necessidade de uma orientação de qualidade, com maior substância. Quando o feedback parte do afetivo todos sentem que há um clima para este retorno, não há condenações, nem punições e sim aprendizado em equipe, um debate saudável sem julgamentos, não há melhor ou pior, mas uma turma que deseja crescer em conjunto. Este enlace do feedback com afetividade corrobora com o processo, cria um vínculo que favorece toda a educação, é um grande ponto positivo, limiar e construtor dentro do processo/arte da EAD. Quando se pressupõe que a arte está condicionando e cooperando com a educação, podemos visualizar de longe o feedback, ele gera comportamento cíclico por meio do compartilhamento de ideias, ideais e referências na atuação do aluno junto à educação. O feedback interliga vários pontos, desde a qualidade, a escolha da instituição a estudar, satisfação e autossatisfação do aluno que participa do processo, socialização e evolução dentro da sociedade. Estimulá-lo a participar por meio do feedback é uma arte gratificante, somente consegue realizá-lo aqueles que se qualificam para tal feito. Deixa de ser um simples trabalho e passa a ser de interesse de todos, dedicação, inclusão digital, social, midiática, cultural e educacional. Torna-se arte quando bem distribuído, formatado, justo, realizado, e que não seja apenas crítico e sim na medida certa da evolução do conjunto. Quando agraciado com motivação, se torna estímulo, preponderante, preciosas devolutivas, com saber e com prazer. É representatividade, influência, estímulo, aprendizado, contribui para uma nova vida, nova formação criativa. O feedback não se propaga sozinho, trabalha na busca de resultados que possam superar e gerar novos conhecimentos. A arte não se motiva, mas influencia, não se cria, mas se recria, é cíclica e originária de novos trabalhos, estudos e focos dentro da própria educação. Feedback é arte positiva, cria motivação, lembranças e representatividade para trabalhos futuros, ao mesmo tempo em que quando deixa a desejar também influencia, porém negativamente, causando retração, não socialização do aluno perante aos demais e com o próprio professor/tutor. O negativo gera o retrocesso no que estava ou deveria estar sendo realizada, a retração condena e intimida conferindo ao professor tutor a figura de juízo.

\section{A EAD COMO INTERLIGAÇÃO NO PROCESSO DE ENSINAR - FEEDBACK EM OPOSIÇÃO A EVASÃO}

Um grande problema no ensino por meio da EAD é evasão. O aluno que pretende cursar neste método geralmente possui maior idade, não possui recursos de acompanhar o ensino da forma tradicional, tem ciência e noção do que deseja e busca melhores oportunidades. O ensino através da EAD é um velho conhecido do aluno, porém ao longo dos anos foi motivo de descrença e piadas, já houve por meio de rádio e cartas, era bastante difundido, por alguns utilizados e por 
outros satirizados. É de responsabilidade e ciência do aluno que deve empenhar-se para concluir e continuar seus estudos, é o maior interessado e contemplado neste método, é dele e para ele a importância. Por mais que o tutor busque integrá-lo, motivá-lo, acompanhá-lo, tem que ter interesse em seu sucesso educacional. Depende do aluno, mas possui grande influência por parte do professor que o motiva. Os alunos mais jovens necessitam passar pela fase do presencial e geralmente não se adaptam com tanta facilidade a EAD, sofrem choque cultural e consequente índice nos números de evasão escolar. Sentem-se deslocados sem o convívio direto com os colegas, atividades presenciais e horários fixos. O aluno quando não ambientado, não cria vínculos com a instituição, sentindo-se deslocado, acarretando retrocesso em seus iniciais interesses, tendendo à evasão. Aí se localiza a afetividade como ligação a ser realizada com o tutor. A afetividade e a arte do feedback trabalham para o bom ambiente educacional, e o emocional como motivo para a não desistência da evasão. $\mathrm{O}$ aluno que se sente parte do processo tem maior socialização, sente-se parte da "equipe" e busca interagir em todas as atividades, evitando a redução de suas contribuições ao ponto que desista do curso. A evasão acarreta ao país perda de recursos quando investidos em programas que financiam estudos, pois poderiam estar favorecendo outros alunos ao invés destes que que não se sentem ambientados com a realidade e ativos dentro do processo. O feedback pode colaborar também neste fator, uma vez que atua na raiz da questão, é ponto importante na não evasão, como essencial e especial para que a socialização seja compensador e não se encontre dissociável ao meio. Se a afetividade é laço forte, ela contrapõe-se à evasão e ambas se anulam e eliminam. A retroalimentação (feedback) é a forma que o ensino possui para que as partes se localizem dentro do processo educacional, é a forma que o aluno possui sua avaliação determinada por seus coordenadores, orienta em suas dúvidas, de modo que o aluno possa trilhar e fomentar novas dúvidas, sugestões e pareceres ao processo. Por outro lado, neste processo, o feedback acaba dentro dos instrumentos de avaliação como sendo formativo e somativo fazendo que o professor compreenda e avalie sua metodologia de ensino para reciclar e trabalhar com melhor qualidade e interação nesta turma e outras mais. A motivação é essencial ao aluno, é integração, influência, liberdade, exposição, capacitação e feedback dentro do processo educacional. É componente ativo e faz com que os alunos interajam com sua educação, seu aprendizado, linha sucessória em seus estudos e capacitação. Esta linha que interliga o feedback e o ensinar são feita pelo professor, porém não só por ele trabalhada, o aluno como ator e não coadjuvante, mas sim participante no processo deve compreender e ativar sua parte. Quando e ao buscarmos falar sobre a motivação dentro do Feedback, sua arte e como ser dado de forma que não seja julgamento e sim aprendizado e crescimento partiu-se dos 
conceitos e aprendizados em aula, também das experiências e participação no curso. A melhor forma de aprender é quando não somente se figura como interlocutor, mas sim participante. Não apenas fornecendo Feedback que se aprende sobre sua importância, e a arte envolvida, seus laços de afetividade, evasão, a sua relação com o ser humano, mas também quando o fomenta. 0 professor é central, mas seus alunos são embasamento para seu aprendizado, o conjunto trabalha vínculos, estimula a não desistir de sonhos, estudos e do aprendizado.

\section{CONCLUSÃO}

Ao analisarmos o feedback concluímos que não pode ser de qualquer forma e a qualquer tempo, tem que se ater ao momento certo, diante de pessoas que o compreendam e ser preparado para uma boa recepção, também quando se fizer necessário, não tendo sentido punitivo e sim orientativo, ser trabalhado como uma arte e não meramente como um efeito solto. O feedback deve ser e é um recurso especial em EAD, pois ele aproxima pessoas, favorece a afetividade e estabiliza o conhecimento.

\section{REFERÊNCIAS}

COSTA, Carolina. Tão longe, tão perto. Revista Nova Escola. Disponível em: <http://revistaescola.abril.com.br/politicas-publicas/modalidades/tao-longe-tao-perto425857.shtml>. Acesso em 10 fev. 2014.

HILSDORF, Carlos. 0 que é Feedback? Disponível em: < http://www.administradores.com.br/artigos/carreira/o-que-e-feedback/64884/>. Acesso em 07 fev. 2014.

MARTINS, Ana Rita e MOÇO, Anderson. Educação a distância vale a pena? Revista Nova Escola, Edição 227 (Nov. 2009). Disponível em: <httphttp://revistaescola.abril.com.br/formacao/formacao-inicial/vale-pena-entrar-nessaeducacao-distancia-diploma-prova-emprego-rotina-aluno-teleconferencia-chat-510862.shtml>. Acesso em 07 fev. 2014.

PORTILHO, Gabriela. Quem é quem na EaD. Disponível em: < http://revistaescola.abril.com.br/gestao-escolar/quem-quem-ead-educacao-distancia-pedagogia697855.shtml>. Acesso em 07 fev. 2014.

VERAS, Márcia. Porque é tão difícil dar e receber feedback? Disponível em: < http://www.endeavor.org.br/artigos/gente-gestao/treinamento-e-desenvolvimento/por-que-etao-dificil-dar-e-receber-feedback>. Acesso em 07 fev. 2014. 